\title{
Effect of temperature on population growth of copepod, Euterpina acutifrons
}

\author{
Marlena Amatus, Najamuddin Abdul Basri, Rossita Shapawi \& Sitti Raehanah Muhamad Shaleh* \\ ${ }_{1}^{1}$ Borneo Marine Research Institute, Universiti Malaysia Sabah, Jalan UMS, 88400 Kota Kinabalu, Sabah, Malaysia
}

${ }^{*}$ Corresponding author: sittirae@ums.edu.my

\begin{abstract}
This study was aimed at determining the optimum temperature for culturing the copepod, Euterpina acutifrons. The trial was conducted for 10 days in chambers at temperatures of $25^{\circ} \mathrm{C}, 27^{\circ} \mathrm{C}, 29^{\circ} \mathrm{C}$ and $31^{\circ} \mathrm{C}$. Ten adult individuals of the copepod were randomly collected and placed into three replicate experimental flasks for each treatment. Throughout the trial, the salinity, light intensity, and photoperiod were maintained at $30 \pm 2 \mathrm{psu}, 100 \mu \mathrm{molm}^{-2} \mathrm{~s}^{-1}$ and 12:12 light-dark cycle, respectively. The copepods were fed with $80,000 \mathrm{cell} / \mathrm{ml}$ Isochrysis sp. daily. At the end of the trial, the total numbers of E. acutifrons nauplii, copepodites and adults were determined and counted using Sedgwick-Rafter. The highest population was found at $27^{\circ} \mathrm{C}$ with mean total population of $800 \pm 100$ individuals from an initial of 10 individuals. This was followed by those reared at $25^{\circ} \mathrm{C}$ and $29^{\circ} \mathrm{C}$ where the population counts were $700 \pm 100$ individuals and $367 \pm 115$ individuals, respectively. At the $31^{\circ} \mathrm{C}$, all the copepod specimens were found dead on day $5^{\text {th }}$. Statistical analysis showed that the temperature had a significant effect $(\mathrm{P}<0.05)$ on the population growth of the copepod. The population of nauplii was higher in lower temperature $\left(25^{\circ} \mathrm{C}\right)$ set compared to the one at higher temperature $\left(29^{\circ} \mathrm{C}\right)$. However, the copepodite number was greater at $27^{\circ} \mathrm{C}$. Growth of the copepod was highest at $27^{\circ} \mathrm{C}(0.438 \mathrm{~K})$ followed by sets at $25^{\circ} \mathrm{C}(0.425 \mathrm{~K})$ and $29^{\circ} \mathrm{C}(0.361 \mathrm{~K})$. Based on the results of this analysis, it is suggested to culture copepod at temperature $25^{\circ} \mathrm{C}$ for nauplii production and $27^{\circ} \mathrm{C}$ for producing more copepodites.
\end{abstract}

Keywords: Aquaculture, Live Feed, Copepod, Temperature, Population growth

\section{Introduction}

A major concern in successful larval rearing of commercial fish is about the appropriate type of live feed at the first feeding phase (Ohs et al., 2009). It is the most critical period in the larviculture that determines the survival of the fish and success of the culture system (Agh and Sorgeloos, 2005). During this phase the marine fish larvae require a live feed of suitable nutritional value and size range (Ohs et al., 2009).

In South East Asia, aquaculture of most species involves capturing young or immature wild stocks and culturing them to marketable sizes. This is an unsustainable practice that contributes to depletion of wild stocks. The viable alternative is establishing the full cycle culture in the hatchery and producing seeds to support aquaculture development. However, the larviculture of most of the species remains a major bottleneck in this effort. Larval mortality is high due to gap in knowledge of nutritional requirement of the larvae and difficulty in producing the required feed suitable for the first feeding (Sorgeloos and Leger, 1992).

At first feeding, the mouth gap of most larvae is small which limits the size of food the larva can capture to survive (Chesney, 2005). Formulated feed, though nutritionally adequate, have been able to replace live feed due to problems pertaining to their digestibility and palatability (Kolkovsky, 2001). The use of rotifer as live feed has revolutionized the development of full cycle culture of many species. The brine shrimp, Artemia, is also used as food for many marine fish larvae due to its commercial availability. However, it has been reported that some species of marine fish do not survive on rotifers and Artemia (McKinnon et al., 2003; Chesney, 2005; O'Bryen and Lee, 2005). These species include Epinephelus sp. (Knuckey et al., 2000; McKinnon et al., 2003; Toledo et al., 2005), Pagrus sp. (Payne, 2000) and Lutjanus sp. (Ogle et al., 2005; Phelps et al., 2005; Su et al., 2005). Comparatively, the copepod provides good results (Stottrup, 2000; Lee, 2003). The advantages of copepods over rotifers and Artemia include size range at the naupliar, copepodite or adult stages. Any of these can be chosen according to the mouth size of the larvae (Chen et al., 2006). Their nutritional content should match the requirements of marine fish larvae (Stottrup, 2000; Evjemo et al., 2003; McKinnon et al., 2003) especially in the amounts of DHA and EPA (Bell et al., 2003). Moreover, their swimming behaviour can stimulate a stronger foraging response in fish larvae (Stottrup, 2000).

Several species of copepods have shown potential in aquaculture particularly in rearing marine fish larvae. The preferred species belong to the genera Acartia, Centropages, Eurytemora, Euterpina, Tigriopus, Tisbe, Oithona and Apocyclops (Stottrup, 2003). The benefits of using copepods as live feed are well known, but reliable supply of copepods remains as a challenge for aquaculture due to technical constraints and it still remains a work in progress (Stottrup, 2000, Hagiwara et al., 2001). The major drawback of copepods as live feeds for larviculture compared to Artemia 
and rotifers is their low productivity in mass culture (Milione and Zeng, 2007; Camus and Zeng, 2008).

In copepod propagation, temperature is one of the main parameters affecting survival and growth. Knowing the optimum temperature will maximize the production of this live feed (Milione and Zeng, 2008). This experiment was conducted to determine the optimum temperature for the population growth of the copepods. Euterpina acutifrons was chosen due to its high potential as live feed for aquaculture.

\section{Materials and Methods}

Experimental trials on the effect of temperature on the growth of E. acutifrons were conducted over a period of 10 days by keeping the cultures in temperature-controlled rooms at salinity of $30 \pm 2$ psu. Four different temperatures of $25^{\circ} \mathrm{C}, 27^{\circ} \mathrm{C}, 29^{\circ} \mathrm{C}$ and $31^{\circ} \mathrm{C}$ were selected for this experiment. The fluctuations in the temperature were about $\pm 2{ }^{\circ} \mathrm{C}$ between day and night. At the beginning of the experiment, adult copepods were separated from stock culture using $200 \mu \mathrm{m}$ sieve. The copepods caught with the help of a mesh and placed in a Petri dish with a small amount of seawater. The specimens were randomly chosen and following the usual isolation procedure transferred to the experimental flasks. This experiment was performed using Erlenmeyer flasks $(250 \mathrm{ml})$ filled with $150 \mathrm{ml}$ of filtered seawater with three replicates for each treatment. Each experimental flask was stocked with 10 adult individuals per $150 \mathrm{ml}$. Adults were used in this experiment due to unavailability of gravid females. Experimental flasks were covered during the experiment to prevent evaporation.

Except the temperature, other experimental conditions, including the salinity $(30 \pm 2 \mathrm{psu})$, light intensity $\left(100 \mu \mathrm{molm}^{-2} \mathrm{~s}^{-1}\right)$ and photoperiod (12:12 LDC) were similar for the sets. Approximately, 80\% culture water was changed daily. The number of copepods was counted at the first and final day of the experiment. The copepods were fed with $80,000 \mathrm{cell} / \mathrm{ml}$ Isochrysis sp. daily based on the results of the previous dietary experiments conducted in laboratory (unpublished work). The amount of feed left was checked daily and the amount of algae fed was adjusted accordingly. Haemocytometer was used to count the algal density. At the end of the experiment, the contents of each replicate bottle were drained through a $20 \mu \mathrm{m}$ sieve and fixed in $10 \%$ formalin solution. The total number of E. acutifrons, nauplii, copepodites and adults were counted using a SedgwickRafter counting slide under optical microscope at 400 times magnification. Results of cell densities were reported as the mean \pm SD of 3 replicate cell counts.

At the end of the experiment, maximum specific growth rate $(\mathrm{K})$ of copepod was calculated using the method used by Levasseur et al. (1993). Two points of $\mathrm{X}_{1}$ and $\mathrm{X}_{2}$ at the extremes of the linear phase were taken and substituted into the equation below:
Growth rate, $\mathrm{K}=\ln \left(\mathrm{X}_{2}\right)-\ln \left(\mathrm{X}_{1}\right) / \mathrm{t}_{2}-\mathrm{t}_{1}$

$\mathrm{X}_{1}=$ initial number of copepods at the start of selected time interval

$\mathrm{X}_{2}=$ final number of copepods at the completion of selected time interval

$\mathrm{t}_{2}-\mathrm{t}_{1}=$ selected time (in days) for the determination of the number of copepods

Where $\mathrm{X}_{1}$ and $\mathrm{X}_{2}=$ biomass at time $1\left(\mathrm{t}_{1}\right)$ and time 2 $\left(\mathrm{t}_{2}\right)$ respectively.

\section{Results}

Figure 1 shows the mean total population of E. acutifrons treated at different temperatures after 10 days of culture. The highest population was recorded at $27^{\circ} \mathrm{C}$ reaching a mean total population of $800 \pm 100$ individuals from an initial 10 individuals of adults per $150 \mathrm{ml}$. This was followed by $25^{\circ} \mathrm{C}$ and $29^{\circ} \mathrm{C}$ with mean total population of $700 \pm 100$ individuals and $367 \pm 115$ individuals, respectively. At $31^{\circ} \mathrm{C}$, all copepods were found dead on day 5 . Statistical analysis showed that the temperature had a significant effect $(\mathrm{P}<0.05)$ on the population growth of E. acutifrons. Final population at $27^{\circ} \mathrm{C}$ was significantly higher than that $29^{\circ} \mathrm{C}$, however, it shows that there was no significant difference $(\mathrm{P}>0.05)$ between $27^{\circ} \mathrm{C}$ and $25^{\circ} \mathrm{C}$.

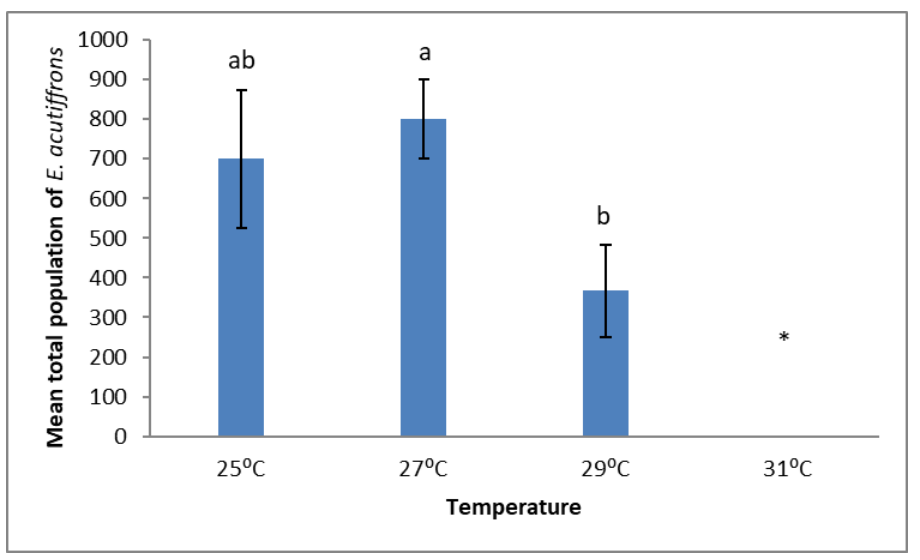

Figure 1. Mean total population of E. acutifrons cultured for 10 days at 4 different temperatures maintained at salinity 30 \pm 2 psu and photoperiod 12:12 light-dark. 


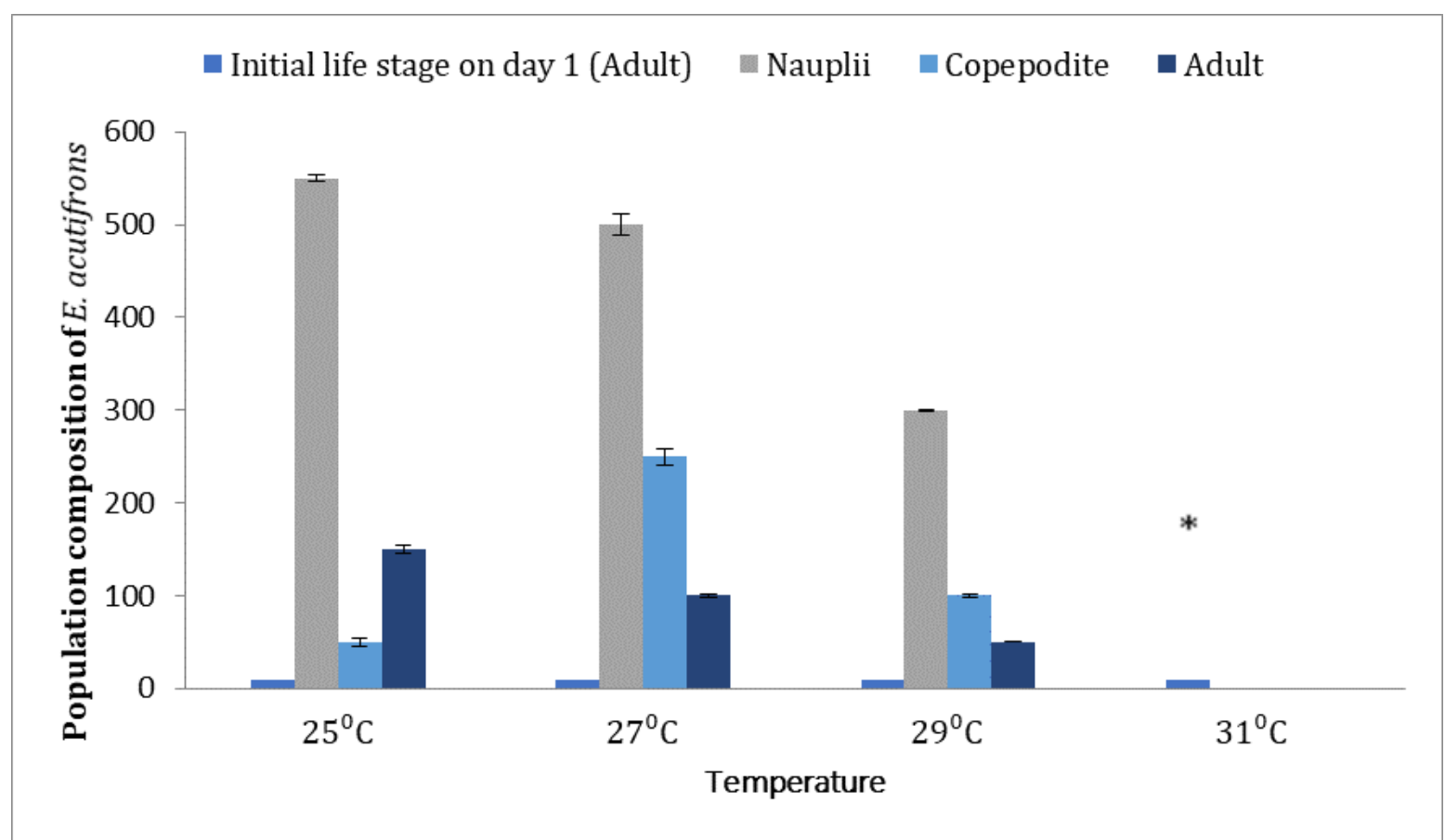

Figure 2. Mean number of individuals at different developmental stages of E. acutifrons cultured in salinity of $30 \pm 2$ psu for 10 days under four different temperatures. * denotes no data on day 10 .

Figure 2 shows the counts of different life stages of $E$. acutifrons at various temperatures at the end of 10 days of culture. The distribution of developmental stages within the population was affected by temperature. In general, the size of the nauplii was between 50 - 200 micron (N1 to N6). At the lower temperatures, the population had a larger number of nauplii compared to the higher temperature. Nauplii were abundant at $25^{\circ} \mathrm{C}$ which were $20 \%$ and $75 \%$ higher than at $27^{\circ} \mathrm{C}$ and $29^{\circ} \mathrm{C}$, respectively. On the other hand, the copepodite ( $\mathrm{C} 1$ to $\mathrm{C} 6$ ) resembling the adult with simple unsegmented urosome and a size range of 200 - 500 micron were more abundant at $27^{\circ} \mathrm{C}$. The results have shown that the copepodite production at $27^{\circ} \mathrm{C}$ was $83.33 \%$ higher than at $25^{\circ} \mathrm{C}$ and $71.43 \%$ higher than at $29^{\circ} \mathrm{C}$. In addition, the total number of adults in the experiment from highest to lowest was $50 \%$ at $25^{\circ} \mathrm{C}, 33.33 \%$ at $27^{\circ} \mathrm{C}$ and $16.67 \%$ at $29^{\circ} \mathrm{C}$. The maximum growth was seen at $27^{\circ} \mathrm{C}$ with $0.438 \mathrm{~K}$ as shown in Table 1 . This was followed by $25^{\circ} \mathrm{C}$ and $29^{\circ} \mathrm{C}$ with $0.425 \mathrm{~K}$ and $0.361 \mathrm{~K}$, respectively.

Table 1. The maximum specific growth rate of E. acutifrons grown in $30 \pm 2$ psu salinity for 10 days under different temperature conditions.

\begin{tabular}{|c|c|}
\hline Temperature $\left({ }^{0} \mathrm{C}\right)$ & Maximum specific growth rate $(\mathrm{K})$ \\
\hline 25 & 0.425 \\
\hline 27 & 0.438 \\
\hline 29 & 0.361 \\
\hline
\end{tabular}

\section{Discussion}

It was observed that E. acutifrons population growth at $30 \mathrm{psu}$ was optimum at $27^{\circ} \mathrm{C}$, with maximum specific growth $0.438 \mathrm{~K}$ although there was no significant difference between $27^{\circ} \mathrm{C}$ and $25^{\circ} \mathrm{C}$. Therefore, it can be suggested that the best range of temperature for culturing of E. acutifrons is between $25^{\circ} \mathrm{C}$ to $27^{\circ} \mathrm{C}$. Previous study on $A$. tsuensis carried out by Takahashi and Ohno (1996) also showed optimal growth and minimum mortality at temperature of around $25^{\circ} \mathrm{C}$. In general, population growth in harpacticoid copepods is highly temperature dependent (Bergmans, 1984), with most rapid growth for tropical species at $\geq 25^{\circ} \mathrm{C}$. The tropical species are better adapted to higher temperature than species in temperate or polar zones (Moreira et al., 1982). Malaysia is a tropical country with a mean annual temperature range of $25^{\circ} \mathrm{C}-28^{\circ} \mathrm{C}$ (Yusoff et al., 1997). Therefore, culturing copepod at these temperatures without using a cooling incubator or air conditioner is possible. This reduces the cost of the live feed production.

Population growth was significantly lower when the temperature increased to $29^{\circ} \mathrm{C}$, with specific growth rate $0.361 \mathrm{~K}$, and all copepods were died at $31^{\circ} \mathrm{C}$. Mortality occurred at $31^{\circ} \mathrm{C}$ is because the temperature increase exceeded the bearing capacity of E. acutifrons. This is apparent by the absence of E. acutifrons at the end of the experiment at $31^{\circ} \mathrm{C}$. In general, the rate of metabolism of organisms increases with increase in temperature (McNab, 2002; Clarke, 2004). The increase is because the reactants in cell gain greater thermal energy and many cellular enzymes become more active as temperature increases. However, when the temperature rises above $30^{\circ} \mathrm{C}$, enzymes become denatured and lose their functional properties (Rhyne et al., 
2009). Similar findings have been observed in Diaptomus pallidus (Geiling and Campbell, 1978), Acrocalanus gibber (McKinnon, 1996), A. sinjiensis (Milione and Zeng, 2008) and Pseudodiaptomus pelagicus (Rhyne et al., 2009).

In this study, the distribution of developmental stages in the population was also affected by temperature. At temperature $25^{\circ} \mathrm{C}$, the population consisted of a greater amount of nauplii. While at $27^{\circ} \mathrm{C}$ and $29^{\circ} \mathrm{C}$, the populations comprised more copepodite stages. For aquaculture, the small size of nauplii can be used for first feeding to a newly hatched fish larvae, while the copepodites are more suitable for the older larvae. Similar trend was observed in an earlier study done by Milione and Zeng (2008) on A. sinjiensis cultured at $30 \pm 1$ psu. According to these authors, the population consisted of a greater number of nauplii at lower temperatures $\left(15^{\circ} \mathrm{C}\right.$ to $\left.24^{\circ} \mathrm{C}\right)$ but consisted of advanced stage individuals at higher temperatures $\left(25^{\circ} \mathrm{C}\right.$ to $\left.34^{\circ} \mathrm{C}\right)$.

\section{Conclusion}

Marine fish hatcheries should consider propagating copepod especially this species $E$. acutifrons as a live feed, considering the size range (50-500 micron) that suits the fish larvae with a smaller mouth gap size (80-150 um) at fist feeding. Based on the finding of this study, the optimum temperature for nauplii production is $25^{\circ} \mathrm{C}$ but for copepodites, the temperature should be $27^{\circ} \mathrm{C}$. For maintenance of stock culture of pure species of $E$. acutifrons, the room temperature should be controlled at $29^{\circ} \mathrm{C}$ as the growth rate is relatively slow and lower rearing efforts will be required.

\section{References}

Agh, N. \& Sorgeloos, P. (2005). Handbook of protocols and guidelines for culture and enrichment of live food for use in larviculture. Artemia \& Aquatic Animals Research Center, 60. Urmia: Urmia University.

Bell, J. G., McEvoy, L. A., Estevez, A., Shields, R. J. \& Sargent, J. R. (2003). Optimising lipid nutrition in first-feeding flatfish larvae. Aquaculture 227, 211-220.

Bergmans, M. (1984). Life history adaptation to demographic regime in laboratory-cultured Tisbe furcata (Copepoda, Harpacticoida). Evolution 38, 292-299.

Camus, T. \& Zeng, C. (2008). Effects of photoperiod on egg production and hatching success, naupliar and copepodite development, adult sex ratio and life expectancy of the tropical calanoid copepod, Acartia sinjiensis. Aquaculture 280, 220-226.

Chen, Q., Sheng, J., Lin, Q., Gao, Y. \& Lv, J. (2006). Effect of salinity on reproduction and survival of the copepod Pseudodiaptomus annandalei Sewell, 1919. Aquaculture 258, 575-582.

Chesney, E. J. (2005). Copepods as live prey: a review of factors that influence the feeding success of marine fish larvae. In Lee, C. S., O'Bryen, P. J. \& Marcus, N. H. (eds.). Copepods in Aquaculture, 133-150, Iowa: Blackwell Publishing

Clarke, A. 2004. Is there a Universal Temperature Dependence of metabolism. Journal of Animal Ecology 18(2):252-256.

Evjemo, J. O., Reitan, K. I. \& Yngvar, O. (2003). Copepods as live food organisms in the larval rearing of halibut larvae (Hippoglossus hippoglossus L.) with special reference on the nutritional value. Aquaculture 227, 191210.
Geiling, W. T. \& Campbell, R. S. (1978). The effect of temperature on the development rate of the major life stages of Diaptomus pallidus Herrick. Hydrobiologia 61, 304-307.

Hagiwara, A., Gallardo, W. G., Assavaaree, M., Kotani, T. \& De Araujo, A. B. (2001). Live food production in Japan; recent progress and future aspects. Aquaculture 200, 111-127.

Knuckey, R., Semmens, G. \& Della-Rodolfa, B. (2000). Research in progress at the Live Prey Research Unit, QDPI Northern Fisheries centre, Cairns. In McKinnon, D., Rimmer, M. \& Kolkovski, M. (eds.). Proceedings of a Workshop on Hatchery Feeds, 9-12 March 2000. Cairns, 35-42.

Kolkovsky, S. (2001). Digestive enzymes in fish larvae and juvenilesimplications and applications to formulated diets. Aquaculture 200, 181 201.

Lee, C. S. 2003. Biotechnology advances in finfish hatchery production: a review. Aquaculture, 227:439-458.

McKinnon, A. D. 1996. Growth and development in the subtropical copepod Acrocalanus gibber. Limnol. Oceanogr., 41:1438-1447.

McKinnon, A. D., Dugan, S., Nichols, P. D., Rimmer, M. A., Semmens, G. \& Robino, B. (2003). The potential of tropical paracalanid copepods as live feeds in aquaculture. Aquaculture 223, 89-106.

McNab, B. K. (2002). The Physiological Ecology of Vertebrates: A View from Energetics. Ithaca, N.Y:Comstock Publishing Associates, Cornell University Press.

Milione, M. \& Zeng, C. (2007). The effects of algal diets on population growth and egg hatching success of the tropical calanoid copepod, Acartia sinjiensis. Aquaculture 273, 656-664.

Milione, M. \& Zeng, C. (2008). The effects of temperature and salinity on population growth and egg hatching success of the tropical calanoid copepod, Acartia sinjiensis. Aquaculture 275, 116-123.

Moreira, G. S., Jillett, J. B., Vernberg, W. B. \& Weinrich, M. (1982). The combined effects of temperature and salinity on the survival of Euterpina acutifrons (Dana) (Copepoda, Harpacticoida) from the New Zealand and Brazilian coasts. Journal of Plankton Research 4, 85-91.

O'Bryen, P. J. \& Lee, C. S. (2005). Culture of copepods and applications to marine finfish larval rearing workshop discussion summary. In Lee, C. S. O'Bryen, P. J. \& Marcus, N. H. (eds.). Copepods in Aquaculture, Blackwell, Melbourne, 245-255.

Ogle, J. T., Lemus, J. T., Nicholson, L. C., Barnes, D. N. \& Lotz , J. M. (2005). Characterization of an extensive zooplankton culture system coupled with intensive larval rearing of red snapper Lutjanus campechanus. In Lee, C. S, O’Bryen, P. J. \& Marcus, N. H. (eds.). Copepods in Aquaculture, 225-244. Iowa: Blackwell Publishing.

Ohs, C. L., Cassiano, E. J. \& Rhodes, A. (2009). Choosing an appropriate live feed for larviculture of marine fish. FA167. University of Florida.

Payne, M. 2000. Cultured copepods as live food for fish. In McKinnon, D. Rimmer, M. and Kolkovski, M. (eds.). Proceedings of a workshop on Hatchery Feeds, 9-10 March 2000, Cairns, 57-62

Phelps, R. P., Sumiarsa, G. S., Lipman, E. E., Lan, H. P., Moss, K. K. \& Davis, A. D. (2005). Intensive and extensive production techniques to provide copepod nauplii for feeding larval red snapper Lutjanus campechanus. In Lee, C. S., O'Bryen, P. J. \& Marcus, N. H. (eds.). Copepods in Aquaculture. Blackwell Scientific Publications Ltd, Melbourne, 151-168.

Rhyne, A. L., Ohs, C. L. \& Stenn, E. (2009). Effects of temperature on reproduction and survival of the calanoid copepod Pseudodiaptomus pelagicus. Aquaculture 292, 53-59.

Sorgeloos, P. \& Leger, P. (1992). Improved larviculture outputs of marine fish, shrimp and prawn. Journal of The World Aquaculture Society 23, 251-264.

Stottrup, J. G. (2000). The elusive copepods: their production and suitability in marine aquaculture. Aquaculture Research 31, 703-711. 
Volume: 04 | Dec 2020, 57 - 61

Stottrup J. G. (2003). Production and nutritional value of copepods. In Støttrup, J. G. \& McEvoy, L. A. (eds.). Live feeds in aquaculture, Oxford, UK: Blackwell Science, 145-205.

Su, H. M., Cheng, S. H., Chen, T. I. \& Su, M. S. (2005). Culture of copepods and applications to marine finfish larval rearing in Taiwan. In Lee, C. S., O'Bryen, P.J. Marcus, N. H. (eds.). Copepods in Aquaculture. Blackwell Scientific Publications Ltd, Melbourne, 183-194.

Takahashi, T. \& Ohno, A. (1996). The temperature effect on the development of calanoid copepod, Acartia tsuensis with some comments on morphogenesis. Journal of Oceanography 52, 125-137.

Toledo, J. D., Golez, M. S., Ohno, A. (2005). Studies on the use of copepods in the semi-intensive seed production of grouper Epinephelus coioides. In Lee, C. S., O'Bryen, P. J. \& Marcus, N. H. (eds.). Copepods in Aquaculture. Blackwell Scientific Publications Ltd, Melbourne, 169-182.

Yusoff, F. M., Subasinghe, R. P. \& Mohd. Zaki, M. S. (1997). Fisheries and aquatic environmental education in Malaysia. In Japar, S. B., Yusoff F. M., Mohd Zaki, M. S. \& Petri, T. (eds.). Fisheries and the Environment: Beyond 2000. 81-88. Serdang, Malaysia: Universiti Putra Malaysia. 